\title{
Empowerment and Product Development of "Terasi Rebon" Processed Seafood Craftsmen as a Leading Potential for Competitive Coastal Areas in Karang Agung, Tuban, East Java
}

\author{
Mahmudah Enny Widyaningrum \\ School of Business and Management, \\ Bhayangkara University, Indonesia
}

\author{
Abdul Fattah \\ School of Business and Management, \\ Bhayangkara University, Indonesia \\ Muslichah Erma W. \\ School of Business and Management, \\ Bhayangkara University, Indonesia \\ Soehardjoepri \\ Mathematics and Applied Science, \\ Tenth November Institut of Technology, Indonesia
}

\begin{abstract}
One of the most prominent products from processed seafood from the famous coastal area of Tuban is Terasi. Terasi is a type of food flavouring in the form of pasta, distinctively smelling fermented shrimp, fish or a mixture of both with salt and other additives. In the implementation of the Regional Superior Product Development Program in partnership with UKM Putra Bahari located in Karang Agung village, Tuban, East Java. Where is the production of shrimp paste as a flavouring cuisine? The problem of partners in terms of the company's production aspects is the production process in which the process of drying raw materials utilizes the availability of sunlight. Where it has an impact on the quality and extent of drying as well as the problem of cleanliness of the process. Then in operational activities have not been done with good operational management, low innovation in production and product variants, so that it needs overall assistance in marketing, financial to tax and production management aspects.
\end{abstract}

Keywords: SMEs Empowerment, Production management, economic management, IT for SMEs

\section{INTRODUCTION}

In terms of attractions and geographical city of Tuban has the potential to suck up tourists. One of the products of the marine wealth of Tuban Regency that has been used as an export commodity is the potential of shrimp. In addition to food crops, exports of various marine commodities are quite meaningful, such as shrimp around Rp. 5.4 billion and anchovies valued at Rp. 46.2 billion. Because seafood in the form of shrimp is very abundant, VIA processes it into food flavouring in the form of shrimp paste, Terasi is a type of food flavouring in the form of pasta, which has a distinctive odour produced by shrimp, fish or a mixture of both with salt or other additives. Almost all countries in South and Southeast Asia have these products, namely Stomp, Ngari, and Tungtap in India, Bagoong in the Philippines, Terasi in Indonesia, 
Belacan in Malaysia, Ngapi in Myanmar, Ka-pi in Thailand. Fish or shrimp paste is usually made from various types of freshwater and marine fish and shrimp (Nugraha, 2006).

The UKM that becomes a partner is a shrimp processing product craftsman namely VIA rebon shrimp paste. Rebon shrimp paste is one of the superior products in the Tuban area. Located in Karang Agung Barat Rt / Rw: 01/01 Ds. Karang Agung Kec. Palang Tuban, East Java, the owner Mr M. Sya'Ronie with the name of the business HM. Putra Bahari.

Generally traded shrimp paste can be divided into two types based on its raw materials namely shrimp paste and fish paste. Shrimp paste usually has a reddish-brown colour, while fish paste is blackish coloured. As mentioned above, ideally the raw material for making shrimp paste is fresh fish or shrimp (rebon). Benefits of shrimp paste: a flavouring enhancer with a distinctive aroma that tastes appetite for various types of food, especially chilli, stir-fry and soup dishes. Nutrients contained in shrimp paste: Based on the raw material for making shrimp paste in the form of shrimp and small fish, it can be concluded that the shrimp paste has a high enough protein, calcium and iodine content. Energy 147 Cal; Protein 30.0 gr; 3.5 gr fat; Carbohydrates 3.5 gr; Calcium 100 mg; 250gr phosphorus.

The following partner issues are reviewed in terms of the operational functions of management:

\section{1) marketing}

Marketing problems experienced by individual companies HM. Putra Bahari limitations in market accessibility. It is unfortunate because rebon shrimp paste has a big market opportunity both for household consumers and business organizations because it is a basic ingredient that has a unique taste that cannot be replaced by other products, and has a competitive price so HM. Putra Bahari with rebon shrimp paste products has no difficulty in gaining markets outside East Java, outside the island and even the export market considering that not all regions can produce it. Because of HM. Putra Bahari has not fully used marketing techniques to open and serve new markets because it does not yet have a showroom or website to display its products.

\section{2) production}

During this time in the production process HM. Putra Bahari invested funds to expand its business premises, 2 units of milling machines, 5 units of wood mixer, 20 pieces of wood molding equipment, boxes for 200 bj shrimp paste drying, 2 Mitsubishi L 300 fleets but did not yet have a dryer from rebon as raw material or shrimp paste which has been produced so that the drying process uses a land of $8 \mathrm{~m} \times 10 \mathrm{~m}$ size so that the unproductive land is highlighted by the unclean of the ongoing process and the hot air.

\section{3) finance}

The activity of the flow of funds occurs imbalance because raw materials have been purchased with the cash system while sales with, among other things, the entrusted sale system, money is taken whenever there is a shrimp paste product that is sold to the central souvenirs. And also restaurants. There is no accounting system and periodic tax reports.

\section{4) Information}

During this time for information activities using face-to-face systems, cell phones, Whatsapp for marketing information systems for consumers are still waiting for consumers who come in the place of sales agents/gift centres. 


\section{5) $\mathrm{HR}$}

Currently, there are 8 permanent employees who are their own families. And 20 temporary employees from the area around the HM. Putra Bahari produces. The 20 temporary employees work in accordance with the requirements and wholesale systems.

It can be said by HM. Putra Bahari in carrying out its business activities carried out traditionally without involving technology and others. Start the planning and recording of raw materials is still done simply by the owner himself, namely M.Sya'Ronie.

Problems agreed to be resolved within 3 years are problems of operational management functions which include: Marketing Management, Production, Finance, Information, HR.

\section{SOLUTION}

Based on partner problems related to flavour variants One factor that can foster consumer interest is the product variants provided by the company. Product variants not only concern the type of product (product item) and product line (product line) but also concerning the quality, design, shape, brand, packaging, size, service, guarantee and return that the company must pay close attention to diversity (variants) products produced as a whole (DEWI LESTARI, 2016) and packaging The dimensions of the packaging have their respective roles to produce good and attractive packaging, because the more attractive the packaging is, the more attractive the consumers (Christy \& Ellyawati, 2014). If the form and material of the packaging are standard, then the graphic element on the package can be an important determinant of whether or not a package is attractive. Good packaging design is not only attractive when displayed on a sales rack, but can also convince consumers to buy (Christy \& Ellyawati, 2014). Agreement on proposing solution teams from Ubhara Surabaya and ITS Surabaya with HM partners. Putra Bahari, the solutions offered in this program refer to the objectives of the program, the problems faced by partners, and the capacity of the tertiary institution. It should also be noted that this program not only provides benefits to partners only, but also provides benefits to related parties including: UPT Quality Development of Industrial Products and Creative Technology Surabaya Department of Industry and Trade of the Government of East Java Province, Department of Fisheries and Animal Husbandry District Tuban in this program so that this mutually beneficial partnership can run continuously.

As a professional organization, operational management must be carried out. At HM. Putra Bahari operational management that is very urgent is the financial side and consistency in paying taxes. Financial management is important to learn for many people who want to use their money as effectively and efficiently as possible, especially for those who want to do business. As Kepher Petra from Kisii University said, financial management is one of the fields that focus on the efficient and effective use of capital, borrowed money and other business funds and the right decision-making process to maximize profits and add value to an entity (Rinaldi, 2015).

\section{Finance}

So far the operational activities have not been carried out in a professional manner. it is necessary to strengthen knowledge of the functions of financial management operations. Namely making financial reports continuously every month along with the tax returns.

\section{Solution:}

Financial management operational activities so far have not been carried out in a professional manner so far, it is still carried out with the family system, considering that permanent employees are from their own families, so those related to finance are held by the owner, Mr M. 
Sya'Ronie. So to prepare as an organized and professional organization strengthening and regular accounting is needed along with preparing tax reporting as a government regulation for SMEs.

\section{Benefits:}

1. Maximize profits with the right decision.

2. Maintain cash flow to be appropriate in order to pay all the obligations and expenses of the company.

3. Prepare capital structure that can be obtained from internal or external.

4. Appropriate and optimal use of money so that efficiency is maintained.

5. Maximizing wealth so that dividends to shareholders and retained earnings can continue to be optimal.

6. Efficiency so that financial distribution is right in all aspects of the company. (Rinaldi, 2015)

\section{Marketing}

HM private company. Putra Bahari in marketing its products is still limited. conducted in a conventional manner so that marketing is still limited around the East Java region. Updating product information through e-commerce in order to expand the marketing area even to foreign countries. Growth in the number of internet users in 2011 is also predicted to experience a very good increase, even observers predict this year the number of internet users in Indonesia has reached more than 50 million people (Bisnisukm, 2011). Of course, if you see the facts above is a very large market share for producers to reap profits. What a very lucrative prospect (I 'in Endang Mardiani, 2013).

\section{Solution:}

In terms of marketing of shrimp paste HM. Putra Bahari is still done limitedly to expand marketing so it is done by the use of IT in marketing. With the use of HM websites. Putra Bahari is able to add 2-3 regions of wider raw material source products with better quality.

HM Partners. Putra Bahari has a website that can be used and can be accessed by customers and prospective buyers from other regions, outside the city and even abroad

Thus the superior products from Tuban are increasingly known. With the increase in the income of SMEs, the regional original income has also increased.

\section{Packaging benefits and flavours:}

1. Expanding the use and marketing of products, for example, the sale of soy sauce and syrup which has also increased since the use of packaging on bottles is applied.

2. Adding interest in potential customers.

3. As an informative media product and advertising.

4. Provide convenience for users.

\section{Benefits of e-marketing:}

1. Can reach more and wider consumers.

2. Created communication between producers and consumers.

3. Facilitate producers to survey in more detail such as sales, level of interest, price increases, the number of products sold and others.

4. Cost savings rather than advertising. 


\section{METHODS OF IMPLEMENTATION}

In the PPPUD service program plan that shows the steps to solve the problem mutually agreed upon and the participation of partners in the implementation of the program that supports the PPPUD program's targets and outcomes is as follows:

\section{Activity Plan}

Based on the approach method, the activity plan that shows the steps to solve the problem agreed between the Proposing Team and PPPUD Partners is as follows:

I. Preliminary visits to PPPUD partners with preparations include:

a. Contacting partners to convey the aims and objectives of the PPPUD service program.

b. When meeting according to the agreed time agreed upon, conduct initial communication about the planned activities between the Implementing Team and the PPPUD Partner in accordance with the existing problems with the partner. Discuss and determine the schedule for the implementation of activities with the aim to provide solutions to existing problems, the implementation of activities can be conveyed in accordance with what has been mutually agreed between the Implementing Team and PPPUD Partners. Determine and carry out the type of partner participation to support the PPPUD program proposed by the PPPUD Implementation Team in accordance with the problems of the HM partners. Putra Bahari with owner/leader Syah 'Ronnie Ds. Karang Agung Kec. Palang Tuban, East Java.

Increased production capacity and optimization of production processes with appropriate technology called the "Tray Dryer" oven machine. Design, training, assistance in the use and maintenance of oven tray dryer machine technology. The faster production process is usually 2 days with 5 hours of terasi has been processed using an oven tray dryer.

The drying room can be used for other production activities.

The production room is more organized, clean with work equipment arranged so that the production process runs more optimally.

An increase in profits with the use of oven tray dyer technology is estimated at 1-6 months an increase of 50\%, 7-12 months increased to $80 \%$ and thereafter an increase of above $85 \%$. And it is expected to continue to increase in the next month and years.

Development of individual companies HM. Putra Bahari has quite good economic potential and is worth developing. In addition to providing business development benefits, it can increase production capacity to meet market demand and is a superior product from the coastal area of Tuban district. And also have an impact on improving the economy of the area of Tuban.

Steps for a production technology solution as follows:

a. Engineering design of oven tray dryer machine technology. All this time, drying uses a large area that becomes unproductive, lacks cleanliness and relies on the sun's heat.

b. training, assistance in the use and maintenance of oven tray dryer machine technology so that the use of the drying area can be used as a sales centre for trasi or showroom.

c. The practice of making shrimp paste using oven tray dryer machine technology treats and repairs whenever there is damage.

d. Monitoring and assistance after training. 


\section{Improving And Strengthening Operational Management Functions}

The operational function of development management has recently shown that large and medium-sized companies are beginning to experience a shift that was initially static to become more dynamic. These things are then developed into a more dynamic operational management system that is not rigid to changes in order to be able to compete with consumers. To improve the efficiency and effectiveness of company work so as to obtain human resources loyal to individual companies such as HM. Putra Bahari and products that have excellence.

Financial management operational activities so far have not been carried out in a professional manner so far as they are still carried out with the family system considering that the permanent employees are from their own families, so those related to finance are held by the owner, Mr M. Sya'Ronie. So to prepare as an organized and professional organization strengthening and regular accounting is needed along with preparing tax reporting as a government regulation for SMEs.

The steps for operational and financial management solutions are as follows:

a. The proposing team and partners designed the system:

1) SOP for production includes: ordering raw materials, processing, packaging of shrimp paste shrimp paste

2) Financial SOPs include: recording the entry budget and the use of the budget.

3) Labor SOPs include labour recruitment, management, work procedure systems, training procedures, workforce removal procedures.

4) SOP on sales/marketing includes ordering procedures, service procedures.

b. Training, implementation assistance from:

1) Ordering raw materials, processing, packaging shrimp paste shrimp paste

2) Recording of incoming budget and use of budget.

3) Recruitment of workers, management, work procedure systems, training procedures, workforce removal procedures.

4) Ordering procedures, service procedures both offline and online

c. Application of financial and tax reporting practices for HM individual businesses. Putra Bahari

d. Monitoring and assistance after training.

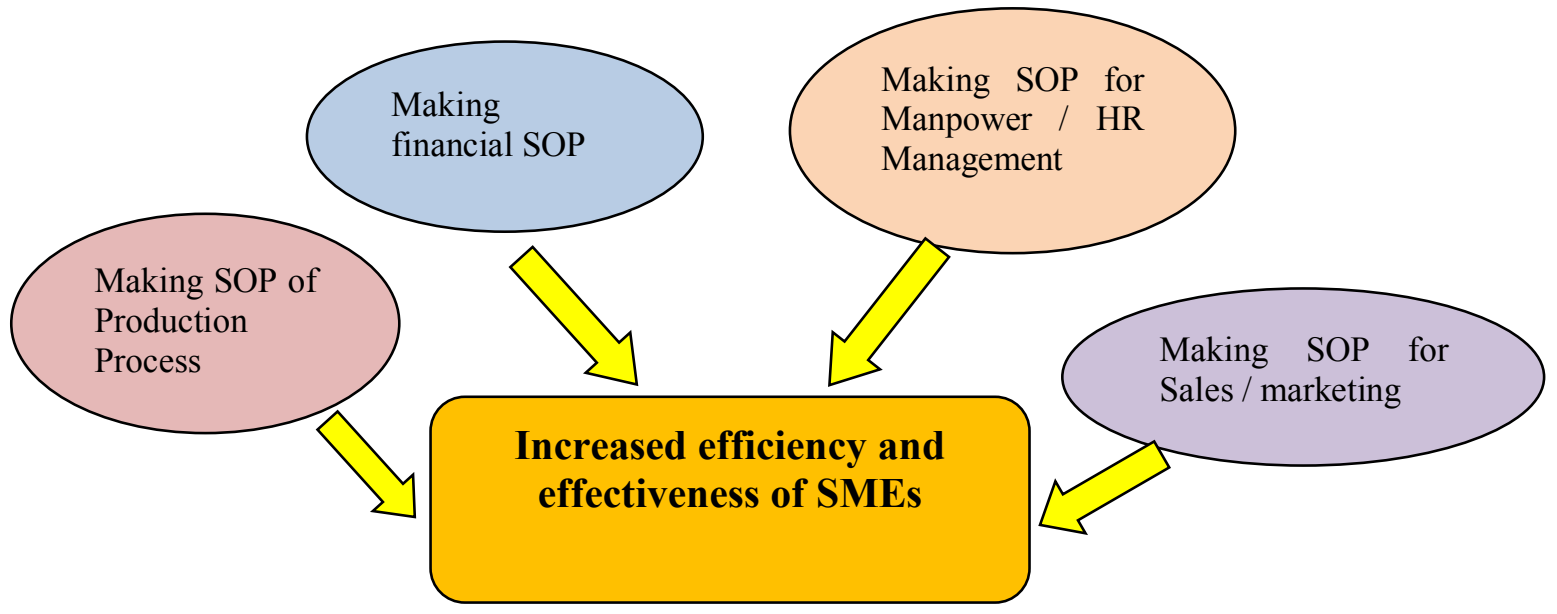




\section{Improvement And Strengthening Of It Use In Marketing}

In terms of marketing of shrimp paste HM. Putra Bahari is still done limitedly to expand marketing so it is done by the use of IT in marketing. With the use of HM website. Putra Bahari is able to add 2-3 regions of wider raw material source products with better quality. HM Partners. Putra Bahari has a website that can be used and can be accessed by customers and prospective buyers from other regions, outside the city and even abroad. Thus the superior products from Tuban are increasingly known. With the increase in the income of SMEs, the regional original income has also increased.

Steps for Solutions to use information technology as follows:

a. Counselling of the internet network to expand the market for sales of shrimp paste which has so far been limited in East Java to be expanded in other regions, outside the island and even other countries. It is expected that Terasi Rebon will still exist as a superior product of Tuban with the use of e-commerce.

b. Training, mentoring on the use of the internet network to expand the market for HM rebon shrimp paste sales. Putra Bahari which has so far been confined to the East Java region to be expanded in other regions, outside the island and even other countries.

c. The practice of utilizing internet networks to expand the sales of Rebon HM shrimp paste. Putra Bahari which has so far been confined to eastern Java to be expanded in other regions, outside the island and even other countries. Terasi rebon still exists as a superior product of Tuban with the use of e-commerce;

\section{1) Promotion}

With the aim to introduce HM. Putra Bahari and its superior products to be easily accessed. Will be made the website and social networking media. Registering on B2B website at P3ED (Regional Export Training and Promotion Center), BPEN (National Export Development Agency, sending profiles at embassies, chambers of commerce and sea product exhibitions. For this reason it is recommended to recruit 1 employee in the IT field as well as staff marketing.

\section{2) Place}

The arrangement of the location of the showroom as the central area of Tuban rebon paste and the arrangement of the office to be more organized and attractive for prospective buyers who come to visit directly. Spatial planning also includes product displays that are marketed. For buyers who buy online, the website will be optimized as a product display and communication channel that facilitates the transaction process.

\section{Partner Participation in Program Implementation}

HM participation. Putra Bahari in the implementation of the third-year program are as follows:

a. Facilitating and providing a place for PPPUD training, practice and mentoring activities on Design (design) and updating (update) website (Wordpress) information on shrimp paste products with various flavours and packaging.

b. Socialization and mobilization to HM employees. Putra Bahari so that all attend the PPPUD training, practice and mentoring activities.

c. Facilitating the formation of an executive committee consisting of the PPPUD implementation team and partners and in charge of providing guidance and information to HM employees. Putra Bahari.

d. Facilitate and provide input to the PPPUD team for the success and smooth running of activities in accordance with the output targets of each PPPUD activity.

e. Help prepare the needs of supporting training activities, practices, and assistance and other infrastructure that does not allow the team to bring from the Higher Education. 


\section{CONCLUSION}

From the results of this activity, it can be concluded that the following points for MSMEs are basically the main problem they face is not the amount of capital available, but in the management and management functions. The problems of management and governance of MSMEs that tend to be unprofessional cause their difficulty to develop. Even though they have good products, resistance and unwillingness in developing markets make it difficult for them to compete with similar products.

Answering this need, activities designed for MSMEs include improvements in quality and production capacity, production management, financial management so that they are transparent and accountable specifically for tax reporting, improvements in resource management and finally the use of technology to support marketing and product diversification.

For further studies, it can be replicated and duplicated from activities that have been carried out for other MSMEs with different business units. The results will not necessarily be the same but can provide a general picture of the implementation and results of activities carried out in the future.

\section{References}

Kubo, M. (2010). The development of an Indonesian national cuisine: a study of new movement of instant foods and local cuisine. Globalization, food and social identities in the Asia pacific region..

Wee, H. M., Jonas, C. P., \& Wang, K. J. (2006, May). An integrated production-inventory model for deteriorating items with imperfect quality and shortage backordering considerations. In International Conference on Computational Science and Its Applications (pp. 885-897). Springer, Berlin, Heidelberg..

DEWI LESTARI. (2016). PENGARUH VARIAN PRODUK, HARGA DAN KUALITAS LAYANAN TERHADAP MINAT BELI KONSUMEN PADA ZYVI CELL PANGKALPINANG, 0-17.

Rinaldi, F. (2015). Pengertian Fungsi dan Tujuan Manajemen Keuangan. Retrieved from https://www.kembar.pro/2015/03/pengertian-fungsi-dan-tujuan-manajemen-keuangan.html

Hari, Y., Dewi, L. P., Santi, C., \& Sembiring, M. J. (2018). Improving Financial Marketing And Accountability With Technology Penetration For The Bag SMEs Community In Gresik, Jawa Timur. Advances in Social Sciences Research Journal, 5(10).

Hari, Y., \& Dewi, L. P. (2018). Forecasting System Approach for Stock Trading with Relative Strength Index and Moving Average Indicator. Journal of Telecommunication, Electronic and Computer Engineering (JTEC), 10(2-3), 25-29..

Widiana, M. E. (2017). Tranformational Leadership Effect On The Marketing Performance Through Market Orientation. Advances in Social Sciences Research Journal, 4(9).Hatanaka, Y., et al. Automated analysis of the distributions and geometries of blood vessels on retinal fundus images. SPIE.

Muslichah Erma Widiana, E. (2014). Model Enhancement for Batik Artisan Empowerment through Customer Relationship Management Approach based on Information Technology. International Journal of Advances in Management and Economics, 3(06), 10-36.Xiaohong, G., et al. A method of vessel tracking for vessel diameter measurement on retinal images. in Image Processing, 2001. Proceedings. 2001 International Conference on.

Widiana, M. E., Hadayati, K., \& Nugroho, A. (2018). Model Enhancement for Batik Artisan Empowerment through Customer Relationship Management Approach based on Information Technology. IJAME.

Fattah, A., Widiana, E., Widiana, M. E., Enny, W., \& Enny, M. (2017). IMPLICATION OF EMPOWERING PARTNERSHIP PROGRAM FOR GROUP OF MANUFACTURERS OF VIRGIN COCONUT OIL IN KELEYAN SUB DISTRICT SOCAH MADURA EAST JAVA. American Academic \& Scholarly Research Journal, 9(6).Pinz, A., et al., Mapping the human retina. Medical Imaging, IEEE Transactions on, 1998. 17(4): p. 606-619. 